\title{
ANALISIS RASIO KEUANGAN DALAM MENGUKUR KINERJA KEUANGAN PT INDOCEMENT TUNGGAL PRAKARSA TBK
}

\author{
Rosyidatul Maulidinah ${ }^{1}$, \\ Gideon Setyo Budiwitjaksono ${ }^{2 *}$ \\ ${ }^{1}$ Fakultas Ekonomi dan Bisnis, Universitas Pembangunan Nasional "Veteran" Jawa Timur \\ Email : rosyidatulmaulidinah73@gmail.com \\ ${ }^{2}$ Fakultas Ekonomi dan Bisnis, Universitas Pembangunan Nasional "Veteran" Jawa Timur \\ *Coresponden Author : gideon.ak@upnjatim.ac.id
}

\begin{abstract}
Indonesia as a developing country always carries out infrastructure development with this development as well as increasing cement production as one of the products needed. For this reason, the company PT Indocement Tunggal Prakarsa TBK needs to conduct financial ratio analysis with the aim of measuring financial performance and as an indicator of changes in the company's financial conditions. Research using quantitative descriptive methods in measuring the financial performance of $P T$ Indocement Tunggal Prakarsa TBK 2015-2019 with the ratio of liquidity, solvency, activity, and profitability. The data collection technique is documentation with secondary data. With the result that the liquidity and solvency ratios show liquid and optimal results, while the activity and profitability ratios are less than optimal.
\end{abstract}

Keywords: Financial Performance, Financial Ratio, Ratio Analysis.

\section{PENDAHULUAN}

Dalam melakukan perbaikan infrastruktur Indonesia melakukan upaya pembangunan secara merata untuk menghilangkan kesenjangan pada setiap daerah. Pemerintah indonesia mengalokasikan dana anggaran APBN untuk pembangunan infrastruktur yang meningkat setiap tahunnya untuk mensukseskan pembangunan infrastruktur tersebut.

Tabel 1 Dana anggaran APBN untuk pembangunan infrastruktur

\begin{tabular}{cc}
\hline Tahun & Anggaran \\
\hline 2015 & 256,1 \\
2016 & 269,1 \\
2017 & 379,7 \\
2018 & 410,4 \\
2019 & 415,0 \\
\hline
\end{tabular}

Sumber : Kementrian keuangan APBN 2019

Dana tersebut naik 4,6 dari tahun 2018. Adanya kenaikan tersebut akan berpengaruh terhadap perusahaan semen sebagai salah satu produk yang di butuhkan dalam pembangunan infrastruktur tersebut. Asosiasi Semen Indonesia (ASI). Menyatakan pada tahun 2019 konsumsi semen di indonesia tumbuh mencapai sekitar 3\%-4\%. Sepanjang tahun lalu, konsumsi semen tumbuh mencapai 4,9\% atau 69,51 juta ton. Perusahaan harus lebih optimal dalam memenuhi target pasar agar dapat memenangkan persaingan dalam industrinya.

Tabel 2 Pangsa Pasar PT Indocement Tunggal Prakarsa Tbk

\begin{tabular}{ll}
\hline Tahun & \multicolumn{1}{c}{ Pangsa Pasar } \\
\hline 2015 & $27,5 \%$ \\
2016 & $26,5 \%$ \\
2017 & $25,3 \%$ \\
2018 & $25,6 \%$ \\
2019 & $25,5 \%$ \\
\hline
\end{tabular}

Sumber : Laporan Keuangan PT Indocement Tunggal Prakarsa

Seiring dengan meningkatnya permintaan semen akan membuka peluang usaha yang besar untuk memberikan produk semen yang berkualitas. Di tengah persaingan industri semen, PT 
Indocement Tunggal Prakarsa Tbk mampu mempertahankan pangsa pasarnya dengan cukup baik. Pada tahun 2018 PT Indocement Tunggal Prakarsa Tbk berhasil meningkatkan pangsa pasarnya menjadi $25,6 \%$ dari tahun sebelumnya sebesar $25,3 \%$. Sedangkan di tahun 2019 pangsa pasar turun menjadi $25.5 \%$ yang mengalami penurunan sebesar $0,1 \%$. Perusahaan harus memperbaiki kinerjanya karena PT Indocement Tunggal Prakarsa Tbk mengalami penurunan laba selama empat tahun terakhir hal tersebut hal tersebut akan berpengaruh terhadap para investor di perusahaan. Untuk mengantisipasi pertumbuhan pasar yang semakin meningkat PT Indocement Tunggal Prakarsa Tbk selalu meningkatkan kapasitas dan realisasi produksi dengan cara menambah jumlah pabrik dan melakukan merger dengan perusahaan semen lainnya.

\section{Gambar 1 Kapasitas dan Realisai produk PT Indocement Tunggal Prakarsa Tbk}

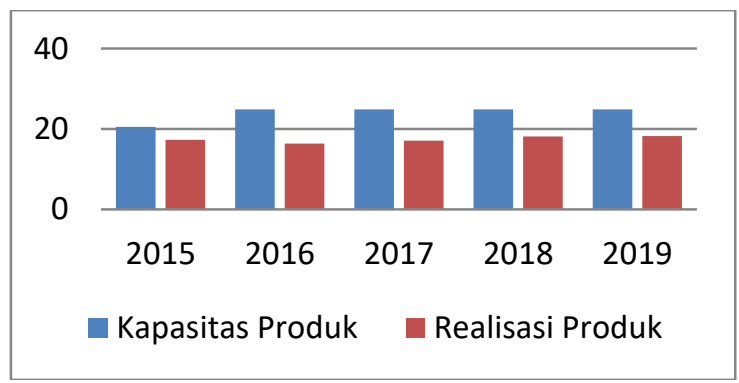

Sumber : laporan keuangan PT Indocement tahun 2015-2019

Persaingan antara industri baik sejenis maupun tidak sejenis perusahaan harus mampu mempertahankan produknya untuk terus berkembang dan terus menghasilkan laba yang optimal dan mampu untuk mengurangi biaya yang di timbulkan dari kegiatan produksi tersebut. PT Indocement yang mengalami penurunan laba dalam empat tahun terakhir sejak tahun 2015 sedangkan di tahun 2019 perusahaan tersebut mengalami peningkatan laba hal tersebut yang membuat penulis ingin menganalisis kinerja dari perusahaan PT Indocement Tunggal Prakarsa TBK dengan menggunakan rasio keuangan berupa rasio likuiditas, solvabilitas, aktivitas dan profitabilitas.

\section{Tabel 3 Laba usaha PT Indocement Tunggal Prakarsa Tbk}

\begin{tabular}{ll}
\hline Tahun & Laba Usaha \\
\hline 2015 & 5.057 \\
2016 & 3.645 \\
2017 & 1.875 \\
2018 & 1.074 \\
2019 & 1.905
\end{tabular}

Sumber : laporan keuangan PT Indocement tahun 2019 (dalam miliaran)

Dari tabel tersebut terlihat laba di tahun 2018 merupakan laba terkecil selama empat periode dari tahun 2015-2018 meskipun perusahaan tetap mengalami laba tetapi penurunan laba secara terus menerus akan mengganggu kegiatan operasional perusahaan. Sedangkan pada tahun 2019 perusahaan sudah mengalami kenaikan laba.

Adanya penurunan laba yang terus-menerus akan berdampak kepada para investor yang mempunyai peran penting dalam perusahaan tersebut. Para pemegang saham akan merasa khawatir apabila kondisi laba yang terus menerus megalami penurunan akan berdampak pada harga saham sedangkan di tahun 2019 laba perusahaan mengalami peningkatan. Kinerja operasional perusahaan yang meningkat dan kapasitas produksi yang meningkat ternyata tidak diimbangi dengan laba yang meningkat di tahun 2018 dan adanya pangsa pasar yang menurun malah mengami peningkatan laba di tahun 2019. Kinerja operasional perusahaan yang meningkat dan kapasitas produksi yang meningkat ternyata tidak diimbangi dengan laba yang meningkat di tahun 2018 dan adanya pangsa pasar yang menurun malah mengami peningkatan laba di tahun 2019.

Pemilihan sistem pengukuran yang tepat akan digunakan sebagai instrumen untuk mengetahui kondisi perusahaan. Dengan pengukuran kinerja perusahaan akan mendapatkan informasi untuk mengetahui kondisi perusahaan. Melalui informasi tersebut maka perusahaan akan melakukan pengendalian dan perbaikan untuk mendapatkan hasil kinerja sesuai yang diinginkan (Hariyanto, 2019). 
Rasio keuangan untuk menunjukkan kinerja perusahaan dengan membandingkan rasio perusahaan selama periode tertentu atau untuk membandingkan dengan rasio keuangan perusahan lain yang sejenis sehingga dapat membantu untuk mengidentifikasi adanya suatu penyimpangan (Rusti'ani \& Wiyani, 2017).

Dari penelitian Karya (2018) mengenai pengukuran kinerja menunjukkan hasil yang kurang baik karena nilai cash ratio, current ratio, ROE dan ROI belum mencapai standar BUMN. Rahmah \& Komariah (2016) dalam penelitiannya menggunakan Rasio keuangan dengan standar industri perusahaan secara umum. Sudah banyak penelitian mengenai kinerja keuangan dan perbedaan dengan penelitian sebelumnya ialah untuk menganalisis kinerja keuangan dengan rasio keuangan yang kemudian diukur dengan standar industri yang digunakan sebagai pedoman keberhasilan suatu rasio keuangan dan dapat melihat bagaimana kemajuan atau kemunduran kinerja keuangan suatu perusahaan. Maka, berdasarkan fenomena tersebut penulis ingin melakukan penelitian berupa "Analisis Rasio Keuangan Dalam Mengukur Kinerja Keuangan PT Indocement Tunggal Prakarsa TBK Tahun 20152019”.

\section{KAJIAN PUSTAKA}

Adanya kinerja yang berkaitan dengan kualifikasi, efesiensi, dan efektivitas perusahaan dalam mengelola bisnis dan untuk melakukan perbaikan pada sistem operasional perusahaan (Rudiwantoro, 2020). Pengukuran kinerja digunakan untuk mengetahui perkembangan keuangandan juga berkaitan dengan pengukuran dan penilaian kinerja (Hery, 2018). hasil yang diperoleh dari kinerja keuangan dapat digunakan perusahaan untuk penunjuk kesehatan keuangan perusahaan (Permata, 2020).

Hasil kinerja perusahaan dari laporan keuangan yang berisi data keuangan yang diukur menggunakan analisis rasio berdasarkan pada laporan keuangan yang digunakan untuk penyampaian informasi kepada pihak lain dan untuk menilai apakah perusahaan sudak efektif (Sanjaya, 2015). Laporan keuangan suatu bentuk tanggung jawab dari pihak manajemen kepada stakeholder atas seluruh aktiva yang ada di perusahaan. Mengukur kinerja keuangan dengan laporan keuangan (Aisyah et al., 2017). Dengan laporan keuangan dapat melihat perkembangan perusahaan secara terus menerus (Jumingan, 2017). Sebagai dasar untuk pengambilan keputusan dan informasi atas data keuangan dan aktivitas perusahaan (Mustofa, 2018)

Proses penelitian laporan hingga menjadi informasi dengan melihat hubungan antara data keuangan dan data nonkeuangan untuk mengetahui kondisi keuangan dan untuk pengambilan keputusan peusahaan (Harahap, 2016). Dengan analisis laporan keuangan dapat mengetahui bagaimana kinerja keuangan baik berupa profitabilitas, sovabilitas, likuiditas maupun aktivitas perusahaan (Hakim \& Rosini 2018). Analisis laporan perusahaan dari perhitungan rasio untuk menilai keuangan perusahaan untuk periode selanjutnya (Syamsuddin, 2011). Sebagai penunjuk hubungan atau sebagai penentu posisi keuangan dari hasil operasi perusahaan (Munawir, 2010). Analisis dengan membandingkan data keuangan yang ditunjukkan pada laporan keuangan (Hanik \& Karyanti 2014). Dari laporan keuangan dapat mengetahui kinerja yang disajikan pihak manajemen (Nurul, 2017).

Cara pengambilan keputusan untuk berinvestasi adalah dengan analisis rasio keuangan (Barus et al., 2017). Dengan analisis rasio dapat menggambarkan gejala yang tampak pada suatu laporan keuangan (Sari, 2019). Analisis rasio keuangan dapat menjelaskan kelemahan dan kekuatan dalam keuangan yang dapat membantu meningkatkan presatasi manajemen dalam periode selanjutnya (Sartono, 2018). Adanya tolak ukur seperti rasio atau indeks dapat digunakan sebagai penilaian kinerja keuangan (Fajrin, 2016).

\section{RASIO LIKUIDITAS}

Rasio likuiditas di sebut sebagai rasio modal kerja yang berguna untuk menunjukkan kinerja perusahaan dalam memenuhi utang jangka pendek untuk dibayarkan (Kasmir, 2016).

\section{Rasio Lancar (Current Ratio)}

Rasio lancar menunjukkan bagaimana perusahaan melunasi utang jangka pendek atau utang yang sedang jatuh tempo untuk di bayarkan (Kasmir, 2016), Rumus :

$$
\text { Current Ratio }=\frac{\text { Aktiva Lancar }}{\text { Utang Lancar }} \times 100
$$




\section{Rasio Cepat (Quick Ratio)}

Quick Ratio untuk menguji cepat bagaimana perusahaan membayar utang jangka pendek dengan aktiva lancar tanpa menghitung persediaan (Kasmir, 2016), Rumus :

$$
\text { Quick Ratio }=\frac{\text { aktiva lancar }- \text { persediaan }}{\text { utang Lancar }} \times 100
$$

\section{RASIO SOLVABILITAS (Leverage Ratio)}

Rasio solvabilitas untuk menghitung bagaimana aktiva suatu perusahaan dapat ditutup dari modal sendiri atau modal pinjaman kepada pihak lain (Kasmir, 2016).

\section{Debt to Asset Ratio (DAR)}

Debt Ratio untuk menghitung pengaruh utang suatu perusahaan terhadap pengelolaan suatu aktiva (Kasmir, 2016), Rumus : Debt to Asset Ratio $=$ Total hutang X 100

Total Aktiva

\section{Debt to Equity Ratio (DER)}

Rasio ini digunkan untuk menghitung bagaimana aset lancar dari modal sendiri digunakan untuk menjamin utang perusahaan (Kasmir, 2016), Rumus :

$$
\text { Debt to Equity Ratio }=\frac{\text { Total Utang }}{\text { Equity }} \times 100
$$

\section{RASIO AKTIVITAS (Activity Ratio)}

Rasio aktivitas untuk menunjukkan tingkat efisiensi suatu perusahaan dalam memanfaatkan seluruh aktiva di perusahaan (Kasmir, 2016).

\section{Perputaran Piutang (Turnover Receivable Ratio)}

Perputaran Piutang untuk menghitung berapa kali perputaran dana piutang dalam satu periode akuntansi (Kasmir, 2016), Rumus :

$$
\text { Perputaran Piutang }=\underset{\text { Rata }- \text { Penjualan }}{\text { Rata Piutang }}
$$

\section{Perputaran Persediaan (Inventory Turnover Ratio)}

Perputaran Persediaan untuk menghitung berapa kali perputaran dana persediaan pada satu periode akuntansi (Kasmir, 2016), Rumus :

$$
\text { Perputara Persediaan }=\frac{\text { Penjualan }}{\text { Rata }- \text { Rata Persediaan }}
$$

\section{Perputaran Modal Kerja (Working Capital Turnover Ratio)}

Perputaran Modal Kerja untuk menghitung berapa kali perputaran dana modal kerja mampu berputar dalam satu periode akuntansi (Kasmir, 2016), Rumus :

$$
\text { NWC Turnover }=\quad \frac{\text { Net Sales }}{\text { Working Capital }}
$$

\section{Perputaran aset tetap (Fixed Asset Turnover Ratio)}

Perputaran aset tetap untuk menghitung berapa kali dana untuk aktiva tetap berputar dalam satu periode akuntansi (Kasmir, 2016), Rumus :

$$
\text { Perputaran Aset Tetap }=\frac{\text { Penjualan }}{\text { Total aktiva tetap }}
$$

\section{Perputaran total aset (Asset Turnover Ratio)}

Perputaran total aset untuk menunjukkan bagaimana penggunaan seluruh aktiva dan mengukur banyaknya penjualan yang di peroleh tiap rupiah aktiva (Kasmir, 2016), Rumus :

$$
\text { Perputaran Total Aset }=\frac{\text { Penjualan }}{\text { Total aset }} \times 1 \text { kali }
$$




\section{RASIO PROFITABILITAS (Profitability Ratio)}

Rasio profitabilitas untuk menghitung kinerja perusahaan dalam mencari laba dan mengukur keefektivitasan manajemen perusahaan (Kasmir, 2016).

\section{Margin Laba Bersih (Net Profit Margin)}

Margin Laba Bersih digunakan untuk mengukur profit margin dengan penjualan yang di ukur dalam bentuk persen (Kasmir, 2016), Rumus :

\section{Return on Investment (ROI)}

$$
\text { Net Profit Margin = laba besih setelah pajak } \times 100 \%
$$

$$
\text { Penjualan }
$$

Return on Investment (ROI) untuk menghitung hasil antara aktiva yang di gunakan atau mengukur ting efisiensi manajemen dalam perusahaan (Kasmir, 2016), Rumus :

$$
\mathrm{ROI}=\frac{\text { laba bersih setelah pajak }}{\text { Total aktiva }} \times 100 \%
$$

\section{Return on Equity (ROE)}

Return on Equity (ROE) menunjukkan laba bersih setelah pajak dengan modal sendiri atau untuk menggambarkan efisiensi dari modal sendiri (Kasmir, 2016), Rumus :

$$
\mathrm{ROE}=\frac{\text { laba besih setelah pajak }}{\text { Ekuitas }} \times 100 \%
$$

\section{METODE PENELITIAN}

Penelitian ini dengan metode deskriptif kuantitatif. Dengan objek penelitiannya perusahaan PT Indocement Tunggal Prakarsa Tbk Periode Tahun 2015-2019 dengan teknik pengumpulan data metode dokumentasi dengan data sekunder yang berupa laporan keuangan yang diterbitkan oleh PT Indocement Tunggal Prakarsa Tbk Periode Tahun 2015 - 2019. Data ini diperoleh melalui website idx yaitu dengan mengakses internet disitus www.idx.co.id.

Teknik analisis dengan pendekatan metode kuantitatif, yaitu dengan menghitung rasio keuangan. variabel dependen dalam penelitian ini adalah kinerja perusahaan pada perusahaan PT Indocement Tunggal Prakarsa Tbk Periode Tahun 2015 - 2019 dan variabel independen adalah pelaksanaan analisis rasio keuangan yang berupa rasio likuiditas, solvabilitas, aktivitas dan profitabilitas. untuk mengukur kinerja PT Indocement Tunggal Prakasa Tbk tahun 2015-2019. Proses analisis data dilakukan dengan tahapan-tahapan yaitu :

1) mengumpulkan data berupa laporan keuangan yang diterbitkan oleh perusahaan.

2) Mengumpulkan data mengenai akun-akun untuk proses perhitungan rasio keuangan dari laporan keuangan perusahaan.

3) Menghitung rasio keuangan, yaitu rasio likuiditas, solvabilitas, aktivitas dan provitabilitas.

4) Membandingkan angka yang diperoleh atau dihitung dengan standar industri yang telah ditetapkan oleh Kasmir.

\section{HASIL DAN PEMBAHASAN}

Berikut perhitungan dengan rasio keuangan yang berupa rasio likuiditas, solvabilitas, aktivitas dan profitabilitas dengan data laporan keuangan yang diterbitkan oleh perusahaan PT Indocement Tunggal Prakarsa Tbk Pada Periode Tahun 2015-2019 sebagai berikut :

\section{RASIO LIKUIDITAS (Liquidity Ratio) Rasio Lancar (Current Ratio)}

Tabel 4 Hasil perhitungan rasio lancar

\begin{tabular}{cccc}
\hline Tahun & Aktiva lancar & Hutang lancar & Current Ratio \\
\hline 2015 & 13.133 .854 & 2.687 .743 & 5 \\
2016 & 14.424 .622 & 3.187 .742 & 5 \\
2017 & 12.883 .074 & 3.479 .024 & 4 \\
2018 & 12.315 .796 & 3.925 .649 & 3 \\
2019 & 12.829 .494 & 3.873 .487 & 3 \\
\hline
\end{tabular}

Sumber : Data sekunder yang di olah, 2021 
Dari perhitungan tersebut menunjukkan bahwa rasio lancar perusahaan di tahun 2015-2016 adalah 5 di tahun 2017 adalah 4 sedangkan di tahun 2018-2019 adalah 3. Rasio lancar tersebut cenderung mengalami penurunan dari tahun 2015-2019.

\section{Rasio Cepat (Quick Ratio)}

Tabel 5 Hasil perhitungan rasio cepat

\begin{tabular}{ccccc}
\hline Tahun & Aktiva lancer & Hutang lancar & Persediaan & Quick Ratio \\
\hline 2015 & 13.133 .854 & 2.687 .743 & 1.521 .197 & 4 \\
2016 & 14.424 .622 & 3.187 .742 & 1.780 .410 & 4 \\
2017 & 12.883 .074 & 3.479 .024 & 1.768 .603 & 3 \\
2018 & 12.315 .796 & 3.925 .649 & 1.837 .769 & 3 \\
2019 & 12.829 .494 & 3.873 .487 & 1.895 .176 & 3 \\
\hline
\end{tabular}

Sumber : Data sekunder yang di olah, 2021

Dari perhitungan tersebut menunjukkan bahwa rasio cepat perusahaan di tahun 2015-2016 adalah 4 sedangkan di tahun 2017-2019 adalah 3. Rasio cepat mengalami penurunan dari tahun 2016 ke tahun 2017 sedangkan di tahun 2017-2019 rasio cepat perusahaan mulai stabil.

\section{RASIO SOLVABILITAS (Leverage Ratio) Debt to Asset Ratio (DAR)}

Tabel 6 Hasil perhitungan Debt to Asset Ratio

\begin{tabular}{cccc}
\hline Tahun & Total hutang & Total aktiva & Debt to Asset Ratio \\
\hline 2015 & 3.772 .410 & 27.638 .360 & $14 \%$ \\
2016 & 4.011 .877 & 30.150 .580 & $13 \%$ \\
2017 & 4.307 .169 & 28.863 .676 & $15 \%$ \\
2018 & 4.566 .973 & 27.788 .562 & $16 \%$ \\
2019 & 4.627 .488 & 27.707 .749 & $17 \%$ \\
\hline
\end{tabular}

Sumber : Data sekunder yang di olah, 2021

Dari perhitungan tersebut menunjukkan bahwa Debt to Asset Ratio perusahaan di tahum 2015 adalah 14\%, di tahun 2016 adalah 13\%, di tahun 2016 adalah 15\%, di tahun 2018 adalah 16\%, sedangkan di tahun 2019 adalah 17\%. Debt to Asset Ratio mengalami penurunan di tahun 2015 dan mulai cenderung meningkat dari tahun 2017-2019.

\section{Debt to Equity Ratio (DER)}

Tabel 6 Hasil perhitungan Debt to Equity Ratio

\begin{tabular}{cccc}
\hline Tahun & Total hutang & Equity & Debt to Equity Ratio \\
\hline 2015 & 3.772 .410 & 23.865 .950 & $16 \%$ \\
2016 & 4.011 .877 & 26.138 .703 & $15 \%$ \\
2017 & 4.307 .169 & 24.556 .507 & $18 \%$ \\
2018 & 4.566 .973 & 23.221 .589 & $20 \%$ \\
2019 & 4.627 .488 & 23.080 .261 & $20 \%$ \\
\hline
\end{tabular}

Sumber : Data sekunder yang di olah, 2021

Dari perhitungan tersebut menunjukkan bahwa Debt to Equity Ratio perusahaan di tahun 2015 adalah 16\%, tahun 2016 adalah 15\%, tahun 2017 adalah 18\%, sedangkan di tahun 2018-2019 adalah 20\%. Debt to Equity Ratio mengalami penurunan di tahun 2016 dan mulai meningkat dari tahun 2017-2019. 
RASIO AKTIVITAS (Activity Ratio)

Perputaran Piutang (Turnover Receivable)

Tabel 7 Hasil perhitungan Perputaran Piutang

\begin{tabular}{cccc}
\hline Tahun & Penjualan & rata-rata piutang & Turnover Receivable \\
\hline 2015 & 17.798 .055 & 2.534 .690 & 7 \\
2016 & 15.361 .894 & 2.605 .323 & 6 \\
2017 & 14.431 .211 & 2.503 .780 & 6 \\
2018 & 15.190 .238 & 2.992 .634 & 5 \\
2019 & 15.939 .348 & 3.021 .217 & 5 \\
\hline
\end{tabular}

Sumber : Data sekunder yang di olah, 2021

Dari perhitungan tersebut menunjukkan bahwa rasio perputaran piutang perusahaan di tahun 2015 adalah 7, tahun 2016-2017 adalah 6 sedangkan di tahun 2018-2019 adalah 5. rasio perputaran piutang cenderung mengalami penurunan di tahun 2015-2019.

\section{Perputaran Persediaan (Inventory Turnover)}

Tabel 8 Hasil perhitungan Perputaran Persediaan

\begin{tabular}{cccc}
\hline Tahun & Penjualan & rata-rata persediaan & Inventory Turnover \\
\hline 2015 & 17.798 .055 & 1.521 .197 & 12 \\
2016 & 15.361 .894 & 1.780 .410 & 9 \\
2017 & 14.431 .211 & 1.768 .603 & 8 \\
2018 & 15.190 .238 & 1.837 .769 & 8 \\
2019 & 15.939 .348 & 1.895 .176 & 8 \\
\hline
\end{tabular}

Sumber : Data sekunder yang di olah, 2021

Dari perhitungan tersebut menunjukkan bahwa rasio perputaran persediaan perusahaan di tahun 2015 adalah 12, tahun 2017 adalah 9 sedangkan di tahun 2017-2019 adalah 8. rasio perputaran persediaan cenderung mengalami penurunan di tahun 2015-2017 sedangkan di tahun 2017-2019 rasio perusahaan tetap stabil.

\section{Perputaran Modal Kerja (Working Capital Turnover)}

Tabel 9 Hasil perhitungan Perputaran modal kerja

\begin{tabular}{cccc}
\hline Tahun & net sales & working capital & NWC Turnover \\
\hline 2015 & 17.798 .055 & 10.446 .111 & 2 \\
2016 & 15.361 .894 & 11.236 .880 & 1 \\
2017 & 14.431 .211 & 9.404 .050 & 2 \\
2018 & 15.190 .238 & 8.390 .147 & 2 \\
2019 & 15.939 .348 & 8.956 .007 & 2
\end{tabular}

Sumber : Data sekunder yang di olah, 2021

Dari perhitungan tersebut menunjukkan bahwa rasio perputaran modal kerja perusahaan di tahun 2015 adalah 2, di tahun 2016 adalah 1 sedangkan di tahun 2017-2019 adalah 2. rasio perputaran modal kerja mengalami penurunan di tahun 2016 dan mulai meningkat dan stabil dari tahun 2017-2019.

\section{Perputaran aset tetap (Fixed Asset Turnover)}

Tabel 10 Hasil perhitungan Perputaran aset tetap

\begin{tabular}{cccc}
\hline Tahun & Penjualan & Total Aktiva Tetap & Fixed Asset Turnover \\
\hline 2015 & 17.798 .055 & 13.813 .892 & 1 \\
2016 & 15.361 .894 & 14.643 .695 & 1 \\
\hline
\end{tabular}




\begin{tabular}{llll}
\hline 2017 & 14.431 .211 & 14.979 .453 & 1 \\
2018 & 15.190 .238 & 14.637 .186 & 1 \\
2019 & 15.939 .348 & 14.080 .158 & 1 \\
\hline
\end{tabular}

Sumber : Data sekunder yang di olah, 2021

Dari perhitungan tersebut menunjukkan bahwa rasio perputaran aset tetap perusahaan di tahun 2015-2019 adalah 1. rasio perputaran aset tetap cenderung stabil dari tahun 2015-2019.

\section{Perputaran total aset (Asset Turnover)}

Tabel 11 Hasil perhitungan Perputaran total aset

\begin{tabular}{cccc}
\hline Tahun & Penjualan & Total Asset & Asset Turnover \\
\hline 2015 & 17.798 .055 & 27.638 .360 & 1 \\
2016 & 15.361 .894 & 30.150 .580 & 1 \\
2017 & 14.431 .211 & 28.863 .676 & 0 \\
2018 & 15.190 .238 & 27.788 .562 & 1 \\
2019 & 15.939 .348 & 27.707 .749 & 1 \\
\hline
\end{tabular}

Sumber : Data sekunder yang di olah, 2021

Dari perhitungan tersebut menunjukkan bahwa rasio perputaran total aset perusahaan di tahun 2015-2016 adalah 1, sedangkan di tahun 2017 adalah 0 sedangkan di tahun 2018-2019 adalah 1. rasio perputaran total aset mengalami penurunan di tahun 2017 dan mulai meningkat dan stabil di tahun 2018 dan 2019.

\section{RASIO PROFITABILITAS (Profitability Ratio)}

\section{Margin Laba Bersih (Net Profit Margin)}

Tabel 12 Hasil perhitungan Margin Laba Bersih

\begin{tabular}{cccc}
\hline Tahun & Laba Bersih Setelah Pajak & Penjualan & Net Profit Margin \\
\hline 2015 & 4.356 .661 & 17.798 .055 & $24 \%$ \\
2016 & 3.870 .319 & 15.361 .894 & $25 \%$ \\
2017 & 1.859 .818 & 14.431 .211 & $13 \%$ \\
2018 & 1.145 .937 & 15.190 .238 & $8 \%$ \\
2019 & 1.883 .349 & 15.939 .348 & $12 \%$ \\
\hline
\end{tabular}

Sumber : Data sekunder yang di olah, 2021

Dari perhitungan tersebut menunjukkan bahwa margin laba bersih mengalami peningkatan di tahun 2015 adalah 24\%, tahun 2016 adalah $25 \%$, tahun 2017 adalah 13\%, tahun 2018 adalah 8\%, sedangkan di tahun 2019 adalah 12\%. margin laba bersih mengalami penurunan di tahun 2017 dan 2018 sedangkan di tahun 2019 mengalami kenaikan.

\section{Return on Investment (ROI)}

Tabel 13 Hasil perhitungan Return on Investment

\begin{tabular}{cccc}
\hline Tahun & Laba Bersih Setelah Pajak & Total Aktiva & ROI \\
\hline 2015 & 4.356 .661 & 27.638 .360 & $16 \%$ \\
2016 & 3.870 .319 & 30.150 .580 & $13 \%$ \\
2017 & 1.859 .818 & 28.863 .676 & $6 \%$ \\
2018 & 1.145 .937 & 27.788 .562 & $4 \%$ \\
2019 & 1.883 .349 & 27.707 .749 & $7 \%$ \\
\hline
\end{tabular}

Sumber : Data sekunder yang di olah, 2021

Dari perhitungan tersebut menunjukkan bahwa Return on Investment perusahaan di tahun 2015 adalah 16\%, tahun 2016 adalah 13\%, tahun 2017 adalah 6\%, tahun 2018 adalah $4 \%$ sedangkan di tahun 2019 adalah 7\%. Return on Investment cenderung mengalami penurunan di tahun 2015-2018 dan di tahun 2019 mulai meningkat. 


\section{Return on Equity (ROE)}

Tabel 14 Hasil perhitungan Return on Equity

\begin{tabular}{lccc}
\hline Tahun & Laba Bersih Setelah Pajak & Equity & ROE \\
\hline 2015 & 4.356 .661 & 23.865 .950 & $18 \%$ \\
2016 & 3.870 .319 & 26.138 .703 & $15 \%$ \\
2017 & 1.859 .818 & 24.556 .507 & $8 \%$ \\
2018 & 1.145 .937 & 23.221 .589 & $5 \%$ \\
2019 & 1.883 .349 & 23.080 .261 & $8 \%$ \\
\hline
\end{tabular}

Sumber : Data sekunder yang di olah, 2021

Dari perhitungan tersebut menunjukkan bahwa Return on Equity perusahaan di tahun 2015 adalah 18\%, tahun 2016 adalah 15\%, tahun 2017 adalah 8\%, ditahun 2018 adalah 5\% sedangkan di tahun 2019 adalah 8. Return on Equity cenderung mengalami penurunan di tahun 2015-2018 dan di tahun 2019 mulai meningkat.

Berdasarkan hasil perhitungan rasio keuangan berupa rasio likuiditas yang terdiri dari current ratio dan quick ratio. Rasio solvabilitas yang terdiri dari debt to asset ratio dan debt to equity ratio. Rasio aktivitas yang berupa receivable turnover, inventory turnover, NWC turnover, fixed asset turnover dan asset turnover. Rasio profitabilitas yang terdiri dari net profit margin, return on investment, dan return on equity dari laporan keuangan perusahaan PT Indocement Tunggal Prakarsa Tbk Pada Periode Tahun 2015-2019 dapat diuraikan sebagai berikut :

Tabel 15 Rasio Keuangan PT Indocement Tunggal Prakasa Tbk

\begin{tabular}{ccccccc}
\hline \multirow{2}{*}{ Rasio Keuangan } & \multicolumn{3}{c}{ Tahun } & $\begin{array}{c}\text { Standar } \\
\text { Industri }\end{array}$ \\
\cline { 2 - 6 } Current Ratio & $\mathbf{2 0 1 5}$ & $\mathbf{2 0 1 6}$ & $\mathbf{2 0 1 7}$ & $\mathbf{2 0 1 8}$ & $\mathbf{2 0 1 9}$ & 3 \\
Quick Ratio & 5 & 5 & 4 & 3 & $2 \mathrm{X}$ \\
Debt to Asset Ratio & 4 & 4 & 3 & 3 & 3 & $1,5 \mathrm{X}$ \\
Debt to Equity Ratio & $14 \%$ & $13 \%$ & $15 \%$ & $16 \%$ & $17 \%$ & $35 \%$ \\
Receivable Turnover Ratio & $16 \%$ & $15 \%$ & $18 \%$ & $20 \%$ & $20 \%$ & $90 \%$ \\
Inventory Turnover Ratio & 7 & 6 & 6 & 5 & 5 & $15 \mathrm{X}$ \\
NWC Turnover Ratio & 12 & 9 & 8 & 8 & 8 & $20 \mathrm{X}$ \\
Fixed Asset Turnover Ratio & 2 & 1 & 2 & 2 & 2 & $6 \mathrm{X}$ \\
Asset Turnover Ratio & 1 & 1 & 1 & 1 & 1 & $5 \mathrm{X}$ \\
Net Profit Margin & $24 \%$ & $25 \%$ & $13 \%$ & $8 \%$ & $12 \%$ & $20 \%$ \\
Return on Investment & $16 \%$ & $13 \%$ & $6 \%$ & $4 \%$ & $7 \%$ & $30 \%$ \\
Return on Equity & $18 \%$ & $15 \%$ & $8 \%$ & $5 \%$ & $8 \%$ & $40 \%$ \\
\hline
\end{tabular}

Sumber : Data sekunder yang di olah, 2021

\section{PEMBAHSAN}

\section{Rasio Likuiditas}

Rasio likuiditas berupa Current Ratio di tahun 2015 dan 2016 menunjukkan bahwa setiap Rp 1 utang akan dijamin dengan Rp 5 aktiva lancar, di tahun 2017 akan dijamin dengan Rp 4 aktiva lancar, di tahun 2018 dan 2019 akan dijamin dengan Rp 3 aktiva lancar. Standar industri untuk Current Ratio adalah 2X sehingga Current Ratio berada di atas standar industri. Berdasarkan analisis rasio tersebut perusahaan sudah efektif dan efisien dalam memaksimalkan aktiva lancarnya sehingga perusahaan dapat membayar utang jangka pendek yang telah jatuh tempo dengan tepat waktu sehingga perusahaan dikatakan dalam keadaan baik atau likuid. Berbeda dengan penelitian Kustiawan (2017) bahwa PT Gunung Salak Sukabumi mengalami kenaikan aktiva lancar tiap tahun dan penurunan utang di tahun 2013 dan 2014 dan kenaikan utang di tahun 2015. Hal tersebut menunjukan bahwa perusahaan memiliki aktiva lancar yang mampu menutupi utang lancarnya, dengan demikian bisa dikatakan bahwa perusahaan masih likuid.

Quick Ratio ditahun 2015 dan 2016 menunjukkan Rp 1 utang akan dijamin dengan Rp 4 aktiva lancar diluar perusahaan, di tahun 2017-2019 akan dijamin dengan Rp 3 aktiva lancar di luar perusahaan. Standar industri untuk Quick Ratio adalah 1,5X sehingga Quick Ratio berada di atas standar industri. Berdasarkan analisis rasio tersebut perusahaan mampu untuk membayar utang jangka pendek dengan kas tanpa menghitung persediaan sehingga perusahaan dikatakan dalam keadaan baik. 


\section{Rasio solvabilitas}

Rasio solvabilitas berupa Debt to Asset Ratio di tahun 2015 memperlihatkan 14\% dari aktiva perusahaan dari utang, di tahun 2016 memperlihatkan 13\% dari aktiva perusahaan dari utang sedangkan di tahun 2017-2019 memperlihatkan 15\%, 16\%, dan 17\% dari aktiva perusahaan dari utang. Standar industri untuk Debt to Asset Ratio adalah 35\% sehingga berada di bawah standar industri. Berdasarkan analisis rasio tersebut menunjukkan bahwa kinerja perusahaan kurang baik karena semakin besar utang yang dimiliki oleh perusahaan tetapi masih berada di tahap aman hal tersebut sejalan dengan penelitian Dewi (2017) bahwa debt ratio pada PT Smartfren Telecom TBK yang menunjukkan kinerja yang kurang baik yang berada di atas standar industri yaitu 35\% yang menunjukkan peningkatan utang kepada pihak kreditur.

Debt to Equity Ratio di tahun 2015 memperlihatkan 16\% dari modal perusahaan dari utang, di tahun 2016-2017 memperlihatkan 15\% dan 18\% dari modal perusahaan dari utang, di tahun 2018 dan 2019 memperlihatkan 20\% dari modal perusahaan dari utang. Standar industri untuk Debt to Equity Ratio adalah 90\% sehingga Debt to Equity Ratio pada berada di bawah standar industri. Berdasarkan analisis rasio tersebut perusahaan masih dikatakan baik karena mampu untuk menjamin utang yang dialami oleh perusahaan. Berbeda dalam penelitian Maith (2013) bahwa rasio debt to equity ratio PT Hanjaya Mandala Sampoerna Tbk tahun 2009- 2012 mencapai 100,9\%. Hal tersebut menunjukkan kinerja perusahaan dalam kondisi yang mengkhawatirkan atau insolvable.

\section{Rasio Aktivitas}

Rasio aktivitas berupa Receivable Turnover Ratio di tahun 2015 menunjukkan perputaran dana dalam piutang sebanyak 7 kali, di tahun 2016 dan 2017 sebanyak 6 kali, di tahun 2018 dan 2019 sebanyak 5 kali. Standar industri untuk Receivable Turnover Ratio adalah 15X sehingga Receivable Turnover Ratio berada di bawah standar industri. Berdasrkan analisis rasio keuangan tersebut menunjukkan adanya perputaran yang kurang baik karena akan semakin lama piutang yang tertanam atau tak tertagih.

Inventory Turnover Ratio di tahun 2015 menunjukkan bahwa perusahaan melakukan perputaran persediaan sebanyak 12 kali, di tahun 2016 sebanyak 9 kali, di tahun 2017-2019 sebanyak 8 kali. Standar industri untuk Inventory Turnover Ratio adalah 20X sehingga Inventory Turnover Ratio berada di bawah standar industri. Berdasarkan analisis rasio tersebut menunjukkan adanya perputaran yang kurang baik karena semakin lama dana yang tertanam pada persediaan sehingga perusahaan kurang maksimal dalam memutarkan dananya.

NWC Turnover Ratio di tahun 2015 menjelaskan setiap Rp 1 modal kerja menghasilkan Rp 2 penjualan, di tahun 2016 menghasilkan Rp 1 penjualan, sedangkan di tahun 2017-2019 menghasilkan Rp 2 penjualan. Standar industri untuk NWC Turnover Ratio adalah 6X sehingga NWC Turnover berada di bawah standar industri. Berdasarkan analisis rasio tersebut menunjukkan adanya perputaran modal kerja yang kurang baik tetapi untuk tiga tahun terakhir menunjukkan peningkatan.

Fixed Asset Turnover Ratio di tahun 2015-2019 menjelaskan setiap Rp 1 diinvestasikan untuk aktiva tetap, menghasilkan pendapatan sebesar Rp 1 dari total aktiva tetap. Standar industri untuk Fixed Asset Turnover Ratio adalah 5X sehingga Fixed Asset Turnover Ratio berada di bawah standar industri. Berdasarkan analisis rasio tersebut menunjukkan adanya perputaran aktiva tetap yang akan menghasilkan keuntungan jika lebih besar dari aktiva tetap.

Asset Turnover di tahun 2015-2016 menurun di tahun 2017 dan meningkat di tahun 2018 dan 2019. Standar industri untuk Asset Turnover Ratio adalah $2 X$ sehingga Asset Turnover Ratio berada di bawah standar industri. Berdasarkan analisis rasio tersebut menunjukkan bahwa perputarannya masih terbilang kurang karena belum mencapai standar industri.

\section{Rasio Profitabilitas}

Rasio profitabilitas berupa Net Profit Margin di tahun 2015 menunjukkan di tahun 2015 dan tahun 2016 sudah menunjukkan hasil persentase yang bagus karena melebihi standar industri yaitu $24 \%$ dan 25\% sedangkan di tahun 2017-2019 cenderung mengalami penurunan yaitu 13\%, $8 \%$ dan $12 \%$. Penurunan terkecil terjadi di tahun 2018 karena laba bersih perusahaan yang semakin menurun dan terjadi kenaikan pada penjualan dan belum mencapai standar industri yaitu $20 \%$ sehingga menunjukkan kinerja yang kurang baik. Hal tersebut sejalan dengan penellitian Suhendro (2017) Net Profit Margin PT Siantar Top Tbk tahun 2011-2013 cenderung mengalami peningkatan, yang disebabkan oleh meningkatnya laba bersih perusahaan dan Pada tahun 2014 menurunnya Net Profit Margin 
menunjukkan kinerja perusahaan yang kurang baik karena laba bersih dari setiap penjualan yang diperoleh perusahaan menurun.

Return on Investment menurun di tahun 2015-2018 yaitu 16\%, 13\%, 6\% dan 4\% dan di tahun 2019 meningkat tetapi belum mencapai standar industri yaitu 30\% sehingga menunjukkan kinerja yang kurang baik. Hal tersebut sejalan dengan penelitian Dewi (2017) bahwa ROI pada PT Smartfren Telecom TBK dalam kondisi yang kurang baik yaitu di bawah standar industri yaitu 30\% yang di sebabkan oleh kerugian bersih akibat tingginya beban usaha yang berasal dari beban operasi, pemasaran dan penjualan.

Return on Equity mengalami penurunan di tahun 2015-2018 yaitu 18\%, 15\%, 8\% dan 5\% karena terjadi penurunan laba bersih setiap tahunnya dan di tahun 2019 mengalami peningkatan menjadi $8 \%$ dan laba bersih mulai meningkat tetapi belum mencapai standar industri yaitu $40 \%$ sehingga menunjukkan kinerja yang kurang atau belum optimal. sama dengan penelitian Oktapiani (2020) bahwa PT Bank Samawa Kencana memiliki kemampuan yang baik dalam menghasilkan laba bersih pada tahun 2017 sampai dengan 2019, tetapi hasil perhitungan ROE tersebut masih berada di bawah standar industri yaitu $32,37 \%, 29,54 \%$, dan $28,24 \%$.

Dari hasil pembahasan menunjukkan bahwa rasio keuangan yang digunakan PT Tunggal Prakarsa Tbk tahun periode 2015-2019 menunjukkan kinerja yang baik untuk rasio likuiditas dan solvabilitasnya sedangkan untuk rasio aktivitas dan profitabilitas masih perlu untuk ditingkatkan lagi untuk mendapatkan hasil yang optimal.

\section{KESIMPULAN}

Dari hasil pembahasan peneliti analisis kinerja keuangan perusahaan dengan menggunakan rasio keuangan yaitu rasio likuiditas, solvabilitas, aktivitas, dan profitabilitas dapat disimpulkan untuk Rasio likuiditas memperlihatkan baiknya kinerja sebab menunjukkan hasil likuid dan mampu menutupi utang serta hasil yang melebihi standar industri. Rasio solvabilitas memperlihatkan baiknya kinerja sebab perusahaan dapat mengendalikan utangnya serta hasil yang kurang dari standar industri, Rasio aktivitas menunjukkan kinerja yang kurang optimal karena terlihat dari perputarannya yang masih kecil serta kurang dari standar industri dan rasio profitabilitas memperlihatkan kinerja yang kurang optimal dalam menghasilkan laba serta berada di bawah standar industri.

\section{SARAN}

Berdasarkan Kesimpulan Diatas, maka peneliti akan memberikan beberapa saran antara lain yaitu :

1. Saran praktis

Untuk meningkatkan rasio lancar dan rasio cepat PT Indocement Tunggal Prakarsa Tbk harus meningkatkan aktiva lancarnya juga dengan cara mengurangi jumlah persediaan yang terlalu banyak, mengurangi penggunaan uang kas agar perusahaan dapat memenuhi hutang lancarnya. Mempercepat perputaran pada rasio aktivitas dengan cara banyak melakukan penjualan dan melakukan merger dengan perusahaan lain agar mampu meningkatkan laba lebih cepat.

2. Saran teoritis

Untuk memaparkan analisis dengan membandingkan dengan standar industri yang digunakan oleh perusahaan lain atau dengan objek perusahaan yang sejenis, menambah periode penelitian, menambah jumlah rasio atau analisis keuangan yang lain seperti analisis tren agar mampu memberikan kebijakan untuk menghasilkan kinerja yang lebih baik lagi.

\section{REFERENSI}

Aisyah, N. N., Kristanti, F. T., \& Zultilisna, D. (2017). Pengaruh Rasio Likuiditas, Rasio Aktivitas, Rasio Profitabilitas, dan Rasio Leverage Terhadap Financial Distress. E-Proceeding of Management Volume 4 Nomor 1 ISSN: 2355-9357, 4(1), 411-419.

Barus, M., Sudjana, N., \& Sulasmiyati, S. (2017). Penggunaan Rasio Keuangan Untuk Mengukur Kinerja Keuangan Perusahaan (Studi pada PT. Astra Otoparts, Tbk dan PT. Goodyer Indonesia, Tbk yang Go Public di Bursa Efek Indonesia). Jurnal Administrasi Bisnis S1 Universitas Brawijaya, 44(1), 154-163.

Dewi, M. (2017). Analisis Rasio Keuangan untuk Mengukur Kinerja Keuangan PT Smartfren Telecom,

Tbk. Jurnal Penelitian Ekonomi Akuntansi (JENSI), 1(1), 1-14. 
Fajrin, P. H., \& Laily, N. (2016). Analisis Profitabilitas dan Likuiditas Terhadap Kinerja Keuangan PT. Indofood Sukses Makmur, Tbk. Jurnal Ilmu Dan Riset Manajemen, 5(6), 01-17.

Hanik, F. U., \& Karyanti, T. D. (2014). Analisis Rasio Keuangan Daerah. 22(2), 143-156.

Harahap, Sofyan Syafri. (2016). Analisis Kritis Atas Laporan Keuangan. Jakarta: Rajawali Pers.

Hariyanto, E. (2019). Analisis Hubungan Strategi Bisnis, Model Pengukuran Kinerja, Kinerja Perusahaan Dan Nilai Perusahaan (Studi Empiris Pada Indeks Islam Jakarta). Behavioral Accounting Journal, 2(1), 99-111. https://doi.org/10.33005/baj.v2i1.36

Hery. (2018). Analisis Laporan Keuangan Integrated And Comprehensive Edition. Cetakan 3. PT Grasindo. Jakarta.

Jumingan. (2017). Analisis Laporan Keuangan. Jakarta: PT. Bumi Aksara.

Karya, E. M. dan K. (2018). Analisis Kinerja Keuangan Menggunakan Rasio Likuiditas Dan Profitabilitas Emi. Jurnal Akuntansi Dan Keuangan Kontemporer, 14(1), 6.

Kasmir. (2016). Analisis Laporan Keuangan. Jakarta: Rajawali Pers.

Kustiawan, D. (2017). Analisis Rasio Keuangan Untuk Mengukur Kinerja Keuangan Perusahaan Pada PT Gunung Salak Sukabumi di Sukabumi. Jurnal Akuntansi Keuangan Dan Perbankan, 7(2), 1321-1336.

Maith, Hendry A. (2013). Analisa Laporan Keuangan dalam Mengukur Kinerja Keuangan Pada PT Hanjaya Mandala Sampoerna Tbk. Jurnal EMBA. 1(3): 619-628. Diunduh melalui : https://ejournal.unsrat.ac.id. (14/12/2019)

Mustofa, Bahrul Ullum. (2018). Pengaruh Kompetensi, Gaya Kepemimpinan Partisipatif dan Budaya Organisasi terhadap Kinerja Karyawan PT Surya Segara Surabaya.

Munawir, S. 2010. Analisis laporan Keuangan Edisi keempat. Cetakan Kelima. Belas. Yogyakarta: Liberty.

Nurul, Suharti, \& Nurhayati. (2017). Analisis Kinerja Keuangan Berdasarkan Rasio Keuangan. 3(2), 297.

Oktapiani, S. (2020). Jurnal Ekonomi dan Bisnis Indonesia. Jurnal Ekonomi Dan Bisnis Indonesia, 5(1), 4-10.

Permata, M. I. (2020). Analisis Rasio Keuangan Untuk Menilai Kinerja Keuangan Perusahaan Pada Pt Dok Dan Perkapalan Surabaya ( Persero ). Jurnal Ilmu Dan Riset Akuntansi, 9(5).

Rahmah, M., \& Komariah, E. (2016). Analisis Laporan Keuangan dalam Menilai Kinerja Keuangan Industri Semen yang Terdaftar di BEI (Studi Kasus PT Indocement Tunggal Prakarsa TBK). Jurnal Online Insan Akuntan, 1(1), 234490.

Rudiwantoro, A. (2020). Mengukur Kinerja Keuangan PT. Pegadaian (Persero) dengan Menggunakan Rasio Keuangan. Moneter - Jurnal Akuntansi Dan KeuanganJurnal Akuntasi Dan Keuangan, 7(2), 205-213.

Rusti'ani, M. E., \& Wiyani, N. T. (2017). Rasio Keuangan sebagai indikator untuk mengukur kinerja keuangan perusahaan semen. Akuntansi, 17(2), 125-138.

Sanjaya. (2015). Pengaruh Disiplin dan Motivasi kerja terhadap kinerja karyawan Hotel Ros In Yogyakarta.

Sari. (2019). Faktor-faktor Penilaian Kinerja Keuangan Pada PT Sinar Roda Utama. Journal of Chemical Information and Modeling, 53(9), 1689-1699

Sartono, Agus. (2018). ManajemenKeuangan:TeoridanAplikasi. Edisi Keempat. Yogyakarta: BPFE.

Suhendro, D. (2017). Analisis profitabilitas dan likuiditas untuk menilai kinerja keuangan pada PT Siantar Top Tbk. Jurnal Ekonomi Dan Bisnis Islam, 4(2), 218-235.

Syamsuddin, Lukman, (2011): Manajemen Keuangan Perusahaan. Jakarta: Rajawali Pers. 